\title{
THE HOBBESIAN TURN
}

\section{Joseph Margolis}

\section{ABSTRACT}

The "Hobbesian turn" is an invention out of whole cloth, a device by which to oppose the usually supposed autonomy of the aesthetic, the moral, the political, and the factual; to recover the collective holism of civilizational (or enlanguaged cultural) life; to feature the existential historicity of the human career, which is incompatible with any strict universalism and all the forms of transcendentalism; hence, also, to feature the adequacy of a contingent Lebensform in collecting the affinities of creative expression and agentive commitment within the terms of human solidarity; to abandon strict universality and necessary synthetic truths; and to favour the fluxive world of pragmatist construction rather than the indemonstrable fixities of rationalism and transcendentalism. The article proceeds largely by examining aspects of Picasso's career and the history of Western politics spanning the sixteenth century to the present.

\section{KEYWORDS}

Civilizational, Existential, Historicity, Holism, Pragmatism, Social Imaginary, Transcendental

I read Hobbes initially as the most strategically placed theorist of Western political history; and I take the vocabulary of Western political philosophy to have become the vocabulary of global politics - which is not to suppose that the West will dominate the political history of the future. ${ }^{1}$ I'm inclined to doubt that it will. I'm persuaded, rather, that we are entering the third phase of a perfectly legible history of distinctly modern politics - fraught with more than ordinary danger - that, from the sixteenth century to the present, has already passed through two prolonged phases distinctive of the West: absolute monarchy and a variety of republican replacements; and is now poised for a third phase that doubtless will borrow in a fresh way elements drawn from the first two phases, now embedded and emboldened in global politics, that may (or may not) be able to leaven the deepening insecurities of our technologized world, which everyone has good reason to fear. My own rather dismal prophecy (I sincerely hope I'm mistaken) is that we are likely to favour one or another form of totalitarian closure and security - within the bounds of which what is usually 
called democratic socialism would have been a welcome option but which I doubt is likely to prevail. Here, we find an enlarged need for conjectural options that have come to be called "social imaginaries": imminent possibilities of political practice, to be precise, drawn from incompletely resolved past insecurities rather than deemed now to be foundationally valid - prudent (in Hobbes' careful sense) more than demonstrably correct in any moral or constitutional way. ${ }^{2}$

There is, I concede, no single correct use of the expression, "social imaginary" and no assured political prophecy but increased insecurity. ${ }^{3}$ My own preference, here, is noticeably shallow, though not unrepresentative or inapt, or unwilling to yield to deeper or more explicit dispositions. In fact, my untutored guess is that cyber technology will assuredly play an increasingly important, partially invisible role, in generating new forms of collective insecurity and in protecting us from same - which suggests the possible congruity of totalitarian options. Seventeenth-century monarchy and eighteenth- and nineteenth-century democracy and republicanism may have suited the prominence of various sorts of individualism that are now being altered or displaced. If so, then there may be a deceptively valid token politics in my conjecture. And if that proves true, then I'm prepared to believe that it will affect artistic, interpretive, and other civilizational sensibilities conformably.

To my knowledge, no one has discussed the Hobbesian aesthetic - as distinct from the Hobbesian politic, which I myself advance with some misgiving, since I take it to be a placeholder for innumerable substitutions of an entwined account of the political and the aesthetic, that I have yet to draft satisfactorily. I treat responsive expression (as in the arts) and responsive commitment (as in politics) as very similar to one another (interpretively) - in terms of the logic of judgment and argument, as well as in being closer to what is thoroughly existential in human life than what is usually urged, say, in executive inquiries regarding morality and the natural sciences. That, however, I concede, may be no more than a personal impression, though it has the effect of demoting the would-be autonomy of moral and factual questions. I treat the primacy of the existential as a factual or ontological discovery - not the cognitive yield of a privileged faculty.

In any event, the two sorts of inquiry appear to converge in their preference for genre-like and prototypical or analogical forms of inference: highly informal, ad hoc, opportunistic, context-bound; unquestionably contingent though logically fortified in drawing on the latent inferential features of mundane discourse itself; 
most successful in ordinary and familiar, even if specialized, exchanges, but as averse to settled forms of constitutionalism as its predecessors.

In reading Hobbes under the shadow of the remarkable glosses provided by figures that belong to our own time, visionary figures like Carl Schmitt and perhaps Giorgio Agamben, whose political guesses, I must admit, are unpleasantly close to my own - or mine to theirs, ${ }^{4}$ I mean to feature at least four linked but distinct convictions that are largely settled, factually, as far as the political side of the story is concerned, and that prove at least as instructive when approached in aesthetic terms or (at an even deeper level of analysis) "existentially" (as I prefer to say) - which I associate with a reconceptualization of pragmatism: first, then, the ontological primacy of flux over fixity, which, applied to the human world or to human cognition, takes the unique and ineluctable form of historicity: that's to say, the benign scepticism that reminds us that we always exceed, by temporal extension, (mere history) the evidentiary sources of past cognition, without ever reaching the end of time or necessary truths about the world (that can never be overturned); second, historicity itself, the primal theme of the existentiality of specifically human life (as expression and commitment), that signifies the impossibility of any strictly rationalist or transcendentalist (totalized) closure applied to the world we claim to inhabit - inasmuch as transcendentalism is no more than a species of rationalism committed to the necessary or apodictic systematicity of the whole of reality (as, most notably, in Husserl's Crisis volume, ${ }^{5}$ though also in Kant); third, the discovery that the contract theory of political legitimation (nominally, Hobbes' theory), said to ensure sovereignty, constitutionality, the rule of law, and similar normative constraints deemed conceptually unavoidable, which is itself a futile regress (already known to Hobbes), since the stipulated "state of nature" is never rightly overcome or displaced (constructively) but only paradoxically installed within the bounds of Leviathan itself - thereby obscuring the deeper truth that political order (however, or if ever, legitimated) may be unconditionally risked (beyond all would-be legitimative measures) by proclaiming what, following Hobbes, both Schmitt and Agamben are prepared to affirm as "a state of exception" said to threaten or defeat the mortal existence and viability of whatever we might otherwise claim to have constructed, contractually, as a valid state (the explicit purpose of Hobbes' contract); and, fourth, the increasingly intractable dangers and insecurities that uniquely mark our contemporary world - largely of our own making, but potentially 
unmanageable and fearsome, existentially primary in the face of the dwindling assurances of conventional norms (monarchical, republican, democratic, liberal) - that may indeed begin to count as permanent "states of exception," likely to be thoroughly lawless (in the rationalist sense), very possibly incoherent as well, and at the same time totalitarian in intent (a thoroughly unpalatable mixture). Nevertheless, I think we may be approaching just such a juncture now - which will require its own aesthetic. Count that a "real imaginary," by which artistic expression and interpretive response (existentially informed) never fail to reflect the perceived human condition.

We continue, of course - we must continue - to speak of sovereignty, constitutionality, and their successors; but we must also confess we lack a fully articulated fluxive alternative to the demands of rationalism and transcendentalism. (We cannot continue as before). There is a recuperative practice to be reclaimed, but it's admittedly difficult to define or trust. Nevertheless, I find an unlikely but thoroughly plausible and promising clue, avant la lettre, in (of all places) the evolving aesthetic of the midnineteenth-century revolution in the arts, in France, roughly postManet and Baudelaire, that, intertwined with the politics of liberty, spontaneously promoted something akin to what I'm calling the Hobbesian aesthetic: the fulfilment of the liberty of artistic expression in the form of the liberty of political commitment - the imaginary of the French Revolution - delayed through the end of the nineteenth century and the end of the first World War. Frankly, I regard the option as politically unavoidable and also - if I may say so - as an option implicitly celebrated in the revolution of modern Western painting just mentioned. I pursue the suggestion briefly for its promise - chiefly in terms of Picasso's compelling career.

The paper itself lies in two halves not yet adequately joined. My first two dicta provide for the defeat of classic rationalism and transcendentalism (chiefly directed against Kant), which I address in the second half of the paper. The other two dicta identify the paradoxes that confront the Hobbesian aesthetic itself, which we must find a way of resolving, and which I explore, as I say, tentatively, by way of some notes regarding Picasso's adventurous practice as a very early twentieth-century expression of the same mid-nineteenth-century artistic revolution that continues to evolve beyond the enthusiasms of Picasso's time. I begin to address these puzzles in the first half of the paper, guided by the precept that we must match the courage of the new liberty of artistic expression (already beyond its first hundred years) with a comparable courage suited to a political commitment capable of resolving the 
threatening paradoxes of our actual political situation. My intention is to strengthen the existential and historied nature of our aesthetic responses, which is at best a second thought in Kant's account.

Now, quite suddenly - I confess I had no inkling of the impending event - the highly-regarded American Constitutional lawyer and theorist, Lawrence Tribe, has just reversed himself on the key puzzle of the logic and legality of impeaching the American President, which, on my reading, unmistakably points the way to preferring the insuperable informality of any ultimate law of nations and states, whether ratified in written form or not - a scandal, to be sure, if judged by Hans Kelsen's lights. ${ }^{6}$ Kelsen insists that there must be a Gründnorm for every properly formed state, but he cannot find it, even under Max Weber's prodding. (Tribe does not mention Kelsen or Weber in his book).

If I understand Tribe correctly, there cannot be an explicit (closed) formulation of the grounds for either indicting (criminally) or impeaching (politically) a democratically elected American President: either practice would produce an all-but-permanent chaos of the order of "a state of exception." (This is, of course, no more than my gloss on Tribe's televised statement of May 19, 2018, in advance of any reading of his actual text - now published). ${ }^{7}$ But, thus far at least (in a way that does not depend on Tribe's further argument, or the vagaries of local constitutional conviction), I take Tribe's statement to provide sufficient grounds for a gratuitous endorsement of my own thesis: that's to say, the key to my replacement of a thoroughly rationalist politics by an unblinking pragmatist alternative. I'm persuaded that, once we admit historicity, this becomes the only way by which to disallow the conceptual embarrassments that fasten on such distinctions as "the state of nature," "a state of exception," "the rule of law," "sovereignty," and the would-be determinacy of "constitutionality." We remain permanently at existential risk, if we (as we must) concede that the Head of State - paradigmatically, the Head of a well-formed democratic state - cannot fail to be open to both indictment and impeachment - but only on the strength of the ad hoc arguments of experienced political agents, speaking and acting in accord with their "form of life" - what I call a "second-best" solution, in the face of there being no privileged or determinate alternative. Such arguments are composed of duly "weighted valences" (or habitudes) of practice drawn, inferentially, from the entire Lebensform or Lebenswelt to which they are to be applied. ${ }^{8}$ Foundational legal categories cannot be more than historied habitudes (approximative, open generalizations) drawn from practice and pertinent conviction. Modern historied democracies 
cannot fail to be consensual; but their habitudes are known of course (with adequate certainty) by all those who participate in the political life of the state. There's the point of the reductio of rationalism and transcendentalism, applied to the political (and, indeed, to every other existential engagement with the world). For cognate reasons, there are no rules among the fine arts or their interpretation. We live by habitudes rather than by rules.

I have one further preliminary thought to add before actually beginning. If I'm right in starting this way, then my preamble should yield a pair of strong principles that may indeed justify the division and reconstituted unity of the paper's two halves. The first principle should hold that historicity and either rationalism or transcendentalism - extended to the political world - are irreconcilable; hence, that, if, as I argue, historicity is itself an existential attribute of the human condition (that's to say, an empirically confirmed fact about human cognition), then strict rationalism or transcendentalism must be, at once, self-contradictory - at once, unconditionally true and evidentially subject to the vagaries of historicity - which, if admitted, precludes all would-be apodictically necessary truths. This is indeed the fatal difficulty of Husserl's Crisis volume. It is also, as I argue, unexpectedly opposed, in a decisive way, to Kant's important but baffling Copernican turn (in the first Critique). My aim here is to recover the normal order of cognitive inquiry in every civilizational space: a state of play that deprives every political, interpretive, aesthetic impulse of any a priori privilege against totalitarian drift. Once conceded, it seems natural to invoke the Hobbesian aesthetic tentatively advanced in the first half of the paper. Let me start, again, here - though I have time for little more than an introductory foray.

\section{I}

My intuition is that political behaviour and the expression and interpretation of the artistic impulse are as close to the primal sources of purposive human life at its most existential that we could ever expect to isolate; and that, in spanning collective action and commitment and the public codification of our expressive responses to the human condition - artfully intertwined - we have indeed begun to occupy the "Hobbesian aesthetic." This is already more than a guess, but, also, less than a theory. Goya, whom I more than admire, may be assuredly counted a compelling exemplar. But then, admitting more contrived modes of expression and the continual deflection of democratic energies, so, too, is the Picasso of early cubism and Les Demoiselles d'Avignon. At any rate, I have 
no easy formula of the Hobbesian aesthetic: it's merely one of a multitude of pertinent possibilities. What I offer, however, has the merit of favouring the holist unity of collective life, which standard philosophical theories of the moral and the aesthetic (the Kantian, preeminently) tend to ignore. The mere aggregation of individual lives neglects the political altogether; and the moral (at its most universal) tends to be bloodless, utopian, indifferent to sittlich origins, as well as distinctly ahistorical - which is to say, as indifferent to the existential as one can imagine. True language, I remind you, is inherently collective: the central meanings of its words and the meaning of all we can discern (say) and usefully interpret discursively in both the political world and the art world.

Cognition, I suggest, is not autonomous but existentially dependent at a deeper level of animal life than can be accounted for by way of the mastery of natural language. Language accounts for the paradigmatic role of discursive knowledge; but the absence of discursive concepts at the animal level (nearest the human) accounts (I suggest) for the existential enabling of the human infant's capacity to master discursive concepts at all. That very ability must rely on innate and easily learned perceptual concepts (a Darwinian as well as an Aristotelian thesis, that neither Darwin nor Aristotle fathomed in the modern way): its most originary impulses (those of the evolving human self or person) must be suitably specieswide but, also, artifactually (culturally) informed. I cannot see how a reasonable theory of interpretation - "civilizational," as I'm inclined to say, rather than merely discretely aesthetic, legal, moral, historical, political, medical, or hermeneutic - can possibly be convincingly formulated if it does not begin with the primal intertwining of the political and the expressive. Hence, the fortunes of the theory of art and of the interpretation of artworks are undoubtedly inseparable from the fortunes of our theory of cognition itself. Animals - you will concede - never dispute about knowledge in the human way. Nevertheless, in the wild, they tend not to stray from their accustomed niches; and, already, there, one finds what seems to be the occasional perceptual incipience of the distinction between appearings and things that appear - a caution sometimes strengthened among animals that live with humans. (But I'll refrain, here, if I may, from any Kantian or Hegelian reading of animal perception or conception).

I also find the disjunctive treatment of legal, aesthetic, political, cognitive, interpretive, theoretical, and practical judgments utterly unconvincing, counter-intuitive, in fact - especially as, on the condition given, cognition is itself existentially qualified, 
primordially animal, inseparable from its well-known petitio and endless regress, insuperably contingent, no more than passingly reliable, approximatively diverse, abductive rather than fallible in any infinitist way. ${ }^{9} \mathrm{I}$ regard this sort of construction as a proper glimpse of what pragmatism comes to in our time: a firmer but more concessive tolerance of what can never be brought to any asymptotic close. I take the human form of life to be uniquely historied or historicized (that is, the lives of selves or persons not mere primates); and I hold that historied and rationalist (hence, also, transcendental) forms of cognition are simply incompatible. Hence, exceptionlessly universal, apodictic, unconditionally necessary truths beyond the analytic and the logical are never more than "stipulative" (in C.I. Lewis' well-known sense) - which outstrips Kant's first Critique easily enough. There are no synthetic a priori truths to be discovered. Truth and validity in the human world count as a distinctly modest but functionally adequate affair.

I'm persuaded that there are no ultimate rules of art or politics: whatever rules or norms there are, are already expressions of hegemonic power contending against the prevailing forces of practices (or habitudes) already in play. Occasionally, the very practice of painting, or the production of an arresting innovation in a particular canvas, unmistakably constitutes an originary political impulse that cannot be ignored. I take the stylistic alliance between Picasso and Braque for instance (confined to the artworld within which they jointly launched what we now call analytic cubism) to be, easily, the most daring and consequential political development of the early twentieth-century artworld, demonstrating how to combine politics and expressive innovation in a revolutionary way, in the form of an initially unexplained new canon. If we concede this much, then, by parity of reasoning, Picasso's Les Demoiselles d'Avignon (of the same period: 1907) is an even bolder, almost explicitly political innovation, that signals (in the briefest, most perfunctory way) no more than Picasso's seemingly remote affiliation with cubism (as well as with other such reminders). It dwells instead on quite another stunning bit of daring, which - if I understand what Picasso is up to - signals that perhaps no one but Picasso himself could have so brazenly favoured his "primitive" idiom in his "hegemonic" way. Every direct borrowing from the Demoiselles, by others, might easily betray itself too obviously to be allowed at all. Picasso's feat is a singularity of sorts - addressed to the politics of ordinary life and of the artworld market - but it plainly rattled the artworld both politically and expressively. 
Observe, please, that, with the possible exception of the sculptured cubist head of Fernande - extraordinary feat - this was hardly true of cubism. That fact alone begins to explain how carefully - as in the preliminary studies for the Demoiselles - Picasso tests the extreme simplifications of his final images. The images are deliberately banalized in the Demoiselles, though in a thoroughly novel way: perfectly legibly, completely unadorned, gross but quiet enough, and yet unmistakably assertive and masterly, so that the horror of the brothel world cannot be denied and cannot be relieved, adumbrated (as it is) by the further banality of its unmarked "erasure." How else could we have expressed the same charge memorably in any standard way? Imagine the Demoiselles hung beside a Renoir or a Matisse! Perhaps only Toulouse-Lautrec could have presented the brothel world compellingly with any approximative fidelity. My thought here is that the "aesthetic" I intend is little more than a preliminary conjecture meant to facilitate a speculation of a completely fresh sort. I wouldn't be at all surprised if it eventually collected its initial intuitions in an entirely different spirit. I begin, then, with the straightforward sense that the commitments of political life and the expressiveness of the artworld may come closest to the existential pathos of the whole of our geistlich world, principally through the hegemonic powers of agency and expression - an idea not at all distant from the inevitable elevation of the Marxist "superstructure" to a level of motivational force outstripping the limitations of any merely classbased ideology. Similarly, Picasso absorbs his offending category within the creaturely.

II

You must bear in mind that Braque, the shyer (but also, it seems, the more articulate of the two allies, who, together, launch cubism without much in the way of preliminary explanation), had himself submitted at least six cubist canvases of the 1908 l'Estaque series for the showing of the pending Salon d'Automne, only to have all of them rejected in one sweep, a move said to accord with Matisse's influence and explicit contempt for the very idea of the new cubism, which Matisse addresses later in his own way. What Picasso and Braque make possible, however, is nothing less than a completely novel, all-purpose, two-dimensional schema (with its own third dimension) - to replace, hegemonically, all of the exhausted habits of so-called academic painting and whatever (justifiably or not) might be construed as tepid extensions of the older practice - impressionism, for one. Cubism appeared, in force, as if it had 
had a longer inning than it actually had. It was not unknown or unanticipated, of course: one sees an essential intuition in Cézanne at least. But it descends all at once on the artworld (as a form of expressive liberty), as if from another planet, irresistibly; and it threatens the sufficiency - and barest order - of every other mode of expression by its mere presence. (You must imagine the historical setting and Picasso's immense opportunism and daring).

The fact is, cubism did not need an explanation, once its master forms were displayed; but no multiplication of the artistic decisions that contrived the Demoiselles could quite capture what accounts for what commands our attention there. Each of these ventures exploits a hegemonic strategy, but of very different kinds. Cubism - Picasso's as well as Braque's - invites the fresh participation of the entire company of active painters of the day, as generously as possible: but not without displaying a sizable, seigneurial volume of commanding exemplars. Demoiselles confirms, more mysteriously, more privately, and, in another way altogether, Picasso's solitary hegemony within the age. There's a daring there - even a menace that perhaps no other artist could have contested at the time; and very few could have fathomed even now. I would say, the ultimate theme of the Demoiselles was unconditional liberty - Picasso's exuberance and creative moxie - overtaking even his treatment of the brothel theme. There's Picasso's use of the Hobbesian aesthetic at its most demanding: painting conceived as a political act of highwire confidence. Admittedly, a by-product of a deeper lesson.

Here, I would say, Picasso reveals himself as a subversive innovator, both in the cubist venture and in Demoiselles, though in very different ways. In the cubist work, Picasso (allied with Braque, who favours the elegance of the new style, which Picasso sets himself to master), contributes to the awesome volume and exuberance of the novel work that suddenly appears as a fait accompli. In Demoiselles, Picasso works quite studiously (in a seemingly incongruous style) to dampen the exposé of the brothel world - and succeeds in heightening its effect (and mystery). Picasso seems to have relished the first uncomprehending responses of the usual connoisseurs of his evolving forms (notably: Kahnweiler's predictable uncertainty). The painting is hardly unfinished, of course, though some of its distinctive features - the use of the African masks, the vestigial still-life fruit at the foot of the canvas, the abrupt change of style from the left to the right side of the canvas, the hint of cubist interests, the near-sameness of two of the prostitutes' faces staring at us (implicitly staring at them), and the implied awareness of the right-most figures with indecipherable 
faces - cannot be said to be straightforwardly deciphered. I can even imagine an allusion to Las Meninas. That's to say, I begin to grasp what a viewing of a Picasso (of this kind) might reasonably tolerate or require: something we might well be tempted to call an artistic "imaginary." One often sees a treatment of an arm or a leg in a random Picasso that has appeared elsewhere in Picasso's huge oeuvre, though without explicit linkage.

The Demoiselles is of course finished, but in a way that tolerates (even as it dares us to fathom) the disconnection of its deliberate oddities. And yet, the painting presents an unmistakable warning, and intensity and unity, that cannot be ignored. Indeed, its seeming scatter contributes to its rigor. Ultimately, I'd say it supports Leo Steinberg's sense of the horror of the brothel (remarked in Steinberg's essay, “The Philosophical Brothel” ${ }^{10}$ ); but it's not easy to spell out just how the effect is produced. It's also possible that its horror lies in the indifference with which it may be completely overlooked. But it also eclipses its nominal theme. It's entirely inferential - visually. The tableau confronts us existentially, but not by any consensually explicit rule. The shorthand treatment of the figures, the opportunism of mingled styles, incongruities here and there, all conspire to draw our attention to the "political" judgment - perhaps, then, moral judgment as well, deliberately underplayed. Artistically, apart from the brothel theme, the abrupt use of the African forms seems to have baffled many - if not most - viewers. But that too, of course, is not irrelevant to our understanding of Picasso's unique mastery. The lax mingling of expressive styles is not unlike an unrecorded conversation of different tongues among the unseen viewers of the scene: inevitably male. Picasso gives the impression of linking every possible expressive impulse displayed and every stylistic habitude to his own purpose. Imagine, for instance, reading the faded red and blue streaks at the sides of the canvas as part of the curtain held open by the woman on the left (with raised hand) and the seemingly continuous background white mid-space of the painting all but obscured by the images of the two (twinned) women themselves - perhaps then recalling (in one or another way) the national flag rendered as inexplicit as possible; but, once hinted, then rendered as well, as an extremely abstract indictment. Something less than an innuendo, let us say; but also, always, the effect of the sheer presence of Picasso at work and play in continental Europe.

Whatever may be found in the world - it may be said - makes its visual contribution to the chance unity of whatever construction or selection of things within the world we happen to favour. For 
Picasso, there are no ultimate limits of expression or composition. And thus, there are no rules of closure to consult: not because of the opaque power of political or artistic genius (in any academic since), but because of the brute power of the expressive impulse itself in Picasso's eye and hand. Political and artistic invention require no rule (except perhaps dependently or instrumentally: that's to say, derivatively, in order to ensure Picasso's aesthetic hegemony at least). Here, Hobbes' politics (and the aesthetic analogue of Hobbes' politics) are greatly strengthened by reference to the more contemporary forms of the political realism of theorists like Carl Schmitt and the Lenin of the Russian Revolution, both of whom follow Hobbes in some measure, adjusted to the greater complexities and deepening disenchantment of the modern world. I should add that Hobbes is hardly an arbitrary figure. He appears at the start of modern political history: in particular, with regard to the mortal insecurity of the state and its aggregated citizenry and the significance of favouring prudential values over the usual moral values of Church and Monarchy.

In fact, the entire history of Western politics, from the sixteenth century to the present, has effectively eliminated the determinacy of any rule of sovereignty, the demonstrable constitutionality of law, the primary political function of moral truths, the wouldbe "rule of law" itself, and the universal consensus or assured validity of the true objectives of political life. Imagine! All that is gone now - or reduced to utopian pronouncements that have all but lost their strictest function. Contemporary politics is guided, rather, by the temporal drift of prudential interests regarding the collective power and security of a constitutive people and the legible declension of evolving practice. We proceed by prudential habitude, but argue from principle. Nevertheless, security is existential, mortal, immediately compelling, primordial, ultimate, unsettling, consensually committed beyond any determinate rules; and the creativity of the entire run of the geistlich world - endlessly and diversely productive, expressive, aesthetically engaged, interpretively responsive - cannot be more than allusively confined, as we've just witnessed, in coming to understand Picasso as the vaunted "painter of modern life." Expression is the existential voice that anticipates political commitment: the "theory of interpretation," therefore, cannot fail to accord with the "theory of human practices." But that is of course the Hobbesian aesthetic: the drift from would-be foundational rules (or laws) to opportunistic (but prudential) habitudes. Picasso is, for a longish time, our principal exemplar - disputed (but often, even uncomprehendingly, 
followed by gifted and ungifted artists alike) into an increasingly disenchanted world of chance marketable expression.

Wherever the supposed rules of painting are enforced (as, selfdeceptively, among the academic salons of nineteenth-century France), we have only to invent (it seems) a maverick canon, abandon the older rules, and vie for one or another form of entrepreneurial hegemony. The surprising success of an entire family of cubisms provides the compelling evidence; and the wary competition between Picasso and Matisse confirms the uncertainty of its market life. It may be that our world is changing too quickly to live by strict rules. My own surmise favours instead Wittgenstein's thoroughly unbewildred pronouncement: "When I obey a rule," Wittgenstein observes, "I do not choose. I obey the rule blindly." 11 I find this as much a law of the artworld and of politics and science, as it is of ordinary language. Out of necessity, we live improvisationally without any explicitly closed order - rationally, by approximative tolerances, felt but never precisely measured. We are continually confronted by the impossibility of human fixity. We have eclipsed the salient forms of rationalist closure and find ourselves beset by the deepening insecurities of guarding every form of information and possession. Every age will have its own politics and interpretive zeal. Ours, on the edge of the most daring (most inviting and most dangerous) technologies ever imagined, is obliged to eclipse the proprieties of all past forms of expression and commitment that the race has ever conceived. Part, but only part, of this is centred on the fear of the robotic and the cyborg.

Politically, I think it very possible that the third phase of our extended history will favour a range of totalitarian closure with no more than a dwindling tolerance of democratic liberty that may meet some of Hobbes' up-dated security concerns. In that case, such themes (and the treatment of such themes) as are favoured in Picasso's Demoiselles and (say) Guernica may prove prophetic for a season. In any event, something of the kind is indeed the key to the convergence of the political and the aesthetic as the world made its turn into the twentieth century. I find it more than plausibly confirmed by the Second World War and the deepening turn into the twenty-first century.

To be entirely candid: What I sense here is the increasing rationalization of large parts of the production of managed truths regarding political, economic, medical, moral, religious, artistic, scientific, and allied forms of information and property, increasingly difficult to examine and test directly in any independently confirmable ways - locally or reliably - at the same time our 
expressive capacities are directed to responding meaningfully to the world as it is thus presented. (Very often, even now, we cannot say whether we are inside or outside the bureaucratic "camp" which is to say: we are "inside"). There may even be competing systems of such political spaces, state-centred or not.

III

The twentieth century produced two very large, disastrous experiments involving competing such systems: the Hitlerian and the Stalinist. The twenty-first century appears ready to provide a wider interpenetrating network of both large and small such ventures, with the distinct possibility that the larger variety may actually prove more successful (and more congenial) than the totalitarianisms of the last century.

The problem requires the invention of more stable and more reliable ways of breaching the forms of totalitarian closure. Call that would-be resolution, "social democracy" (new form). I cannot see how the third phase of our political history can escape (at its most fortunate) a contest (or confrontation) between totalitarian closure and the relative openness of social democracy (new form); and I cannot see any assurance that totalitarianism will be benignly contained. One of the most extreme predictions of this sort appears in Agamben's Homo Sacer: the prophecy that the paradigmatic political space of our age will not be the emancipated city but the concentration camp. It may not make much difference if the model is to be no more than the marginally democratized totalitarian state itself. In that event, both the solution and resistance to such a solution will appear as Hobbesian options favoured in much the same way. What emerges is the dawning sense of how the existential nature of our new technologies will impact the artistic and the aesthetic and the mundane political. There cannot be any convincing disjunction between the cognitive (or the discursive) and the existential condition of each. The "existential" forms of historicity will persist with a vengeance; and every pertinent effort to constrain our "technological daring" will (I conjecture) have to come to terms with the "rational appeal" of totalitarianism. There's the point of entertaining the revival of the socialist "imaginary."

I do also mean what I say about the disappearance of sovereignty and the impossibility of solving the ultimate constitutional question. We are now, I would say, on the edge of the third phase of a political history that, for reasons linked to the changing needs of an acceleratingly technologized age, appears to favour the seeming security of populist and totalitarian closure. Expression 
in the geistlich world may be expected to draw its own hegemonies from that elementary but inevitably deceptive fact. Here, you begin to glimpse the plausibility of a theory of interpretation (as well as of artistic production) of the entire (ultimately indivisible) run of civilizational concerns - legal, religious, educational, moral, medical, artistic, hermeneutic - that collects the whole of our "spiritual" world and presupposes the cultural entwinement of the political and the aesthetic. It's the primacy and increasingly technologized dangers of the existential world that we anticipate - a giant step beyond Marxian economism. I cannot see the likelihood of salvaging any form of socialist democracy before we come to grips with the pacification of our growing fears; and I expect that the arts themselves will increasingly feature such concerns.

What already marks the naiveté of Hobbes' rationalist contract is the fiction of a discernible and changeless ground-rule (Gründnorm, in Hans Kelsen's idiom) that vouchsafes any and every would-be legislative system. There may well have been a need for the illusion of such a rule, but there can be none in a thoroughly historied world (our own). There's the failure of rationalism and transcendentalism. The sense of constancy in change is all we have and all we could ever apply - in politics or the artworld or the whole of human practice; and the artworld confirms the viability of the liberty it engenders. There's the ultimate virtue of what I'm calling the Hobbesian aesthetic, most memorably manifested in the delayed revolution of post-academic painting in nineteenthcentury France, possibly the best expression of the true liberté of the French Revolution, construed holistically or organically, as the quality of a viable state.

The political, more than the moral, possibly because of its continually mortal risks, has produced in our time some ingenious (seemingly necessary) conceptual innovations of a realist sort that appear not to have been needed earlier with the same urgency that, say, surfaced with the advent of that profoundly self-contradictory event - at once fatally successful and unquestionably failed - that, changeably characterized, we know as the Russian Revolution. In short, I take the political and the spiritual (the aesthetic, if you wish) to be the twin monitors of our societal well-being, sensed somewhat subliminally in other than principled discursive ways - creaturely ways, I think we may say - existentially, whether accurately or not, by means of what have come to be called "social imaginaries." In my opinion, this begins to suggest a quite plausible way of rescuing John Dewey's notion of a "problematic situation" (politically as well as individually, along existential lines): the effect, let us 
say, of transforming what may be described as animal prudence rendered political by the unique powers of mastering language - a post-Darwinian reading of the bond between Hobbes and Dewey, globalized, possibly even a post-pragmatist pragmatism. ${ }^{12}$

Aggregated agency in the political sense gathers force spontaneously, to ensure the continuing life of an organized cohort of citizens viewed as a collective body; agentive imagination at the juncture of the political and the spiritual often provides no more than dream-like glimpses of the meaning of our actual forms of life. (The artworld always has a surfeit of uncommitted energy). In that sense, the expression and interpretation of our collective identity can afford to remain relatively latent (though easily awakened) in the studio and museum. (It rarely strays far from the political). Nearly all that we say and do obliquely involves that identity. There's the clue to the social integrity of any sizable aggregate of self-directed lives. We absorb the culture of our homeland and we are thereby effectively primed for possible political engagement, as well as for the interpretation of our culture. (The two go hand in hand). The articulation of the political yields a fresh theory of art and the interpretation of art. Its best contribution is that of the dawning sufficiency of practice itself: there is no higher normativity to be had. There's the force of historicity.

I'm inclined to think that the globalized insecurities of our world have been pointedly reawakened in recent years, have begun to rally meaningfully again, with a force and direction that cannot yet be satisfactorily deciphered. Totalitarian, even fascist, fears run through the Western world more insistently now than in recent years. Inchoate currents, the increased incipience of "social imaginaries" may already anticipate the start of a new age. An up-dated Hobbesian innovation, mediated by such politically active figures as Lenin, Schmitt, Antonio Gramsci and, in a more academic mode, Giorgio Agamben and Ernesto Laclau, similarly attracted to Hobbes in the geistlich sense, have indeed confronted the totalitarian option realistically, as well as that of post-Marxian socialism, in terms that now require the novel realisms of the "imaginaries," which of course, are actual but reduced realist options - "possibilities," say - not easily distinguished from one another within the "hegemony" of some (contrived) leadership that is unlikely to succeed without their explicit support. (This, of course, is the decisive lesson of the Russian Revolution that frightened Europe so badly: the onset of Stalin's opportunism, given the failed "hegemony" of the Leninist coup: the absence of an adequate cohort of revolutionaries or of a suitable imaginary). 
Our political (and artistic) future has already been partially limned. We must play out the hand we've dealt ourselves.

The earlier defeat - if I may now call it that - in the nineteenth century, of French academic painting, primed by the initiatives of Manet and his contemporaries and successors, who plied their professional skills entrepreneurially, reminds us that artistic imagination was and is now obliged to create a loyal audience for its altered fashions, at the same time it seeks to sell its wares in the open market. The "hegemonies" of the Hobbesian aesthetic continually alter the mapping of our existential world. Picasso is its most stunning - late - exemplar.

Social imaginaries are the relatively stable collective presences with which a "hegemonic" (ideologically dominant) power (in either politics or art or elsewhere) may realistically consider an accommodating alliance by which to advance the fortunes of cooperating (usually transient) "collectives" in an effort to displace the competing objectives of ventures opposed to the new initiative. The openness, the creative tolerance, say, of the world of post-academic painting, in France, in the latter half of the nineteenth century, is more easily supported than specifically political imaginaries - but it is also often more difficult to interpret accurately in hegemonic terms. It may contribute nevertheless to an ethos hospitable to expressive and potentially political innovations with regard to our existential world. The idea of an intertwining of the political and the aesthetic yields a very plausible (and ample) sketch of the shifting historical orientation of contemporary commitment and expressive imagination ranging over the whole of our civilizational concerns - collected in every possible way against the closure of the totalitarian. I intend all of this informally, but not without conviction. That's to say, the Hobbesian aesthetic is itself a prescient political "imaginary" on the edge of a new encounter with the demands of modern - collective and technologized - life. 
1 I'm afraid l've promised too much in the present paper, "A Hobbesian Aesthetic" (keynote presentation), The Nordic Society of Aesthetics, Annual Meeting 2018, Paris, 31.5-2.6. 2018. This is the full text of the abbreviated talk presented. References not pursued here are to a considerably larger text, essentially drafted but not published, which provides a more rounded sense of its conceptual setting and intention. The idea of a "Hobbesian aesthetic" is meant to support an indissolubly holist account of the "civilizational" intertwining of all of our interests in the arts and the interpretation of the arts, flagged in terms of the inseparability of the aesthetic and the political, nominally directed against Kant. The larger undertaking examines aspects of the Hobbesian aesthetic (a contrived option) in terms of five much-contested matters: (i) the existential primacy of expression and commitment (in art and politics) over the cognitive and the conceptual dependence of the cognitive on the existential regularities of human life; (ii) the ineliminability of the discursive (and the lingual: that is the non-discursive forms of expression that presuppose the discursive-the balletic, for instance) essential to the formation and presence of persons, artworks, words, and actions); (iii) a final reckoning between rationalist and transcendental philosophy and pragmatist informality; (iv) the nature and scope of historicity and normativity; and (v) the legitimation of an inverted unity-of-science conception favouring the primacy of the human sciences over the physical sciences.

2 See Thomas Hobbes, Leviathan, ed. Michael Tuck (Cambridge: Cambridge University Press, 1991 [1651]).

3 See, for instance, Charles Taylor, Modern Social Imaginaries (Durham: Duke University Press, 2004).

4 See Carl Schmitt, The Concept of the Political, expanded ed., trans. George Schwab (Chicago: University of Chicago Press, 2007); and Giorgio Agamben, Homo Sacer: Sovereign Power and Bare Life, trans. Daniel Heller-Roazen (Stanford: Stanford University Press, 1998).

5 See Edmund Husserl, The Crisis of European Sciences and Transcendental Phenomenology: An Introduction to Phenomenological Philosophy, trans. David Carr (Evanston: Northwestern University Press, 1970): including Appendix V; "[Objectivity and the World of Experience]," pp. 343-351.

6 See Hans Kelsen, General Theory of Norms, trans. Michael Hartney (Oxford: Oxford University Press, 1991).

7 Reported on the MSNBC (US) television channel. See, also, Lawrence Tribe and Joshua Matz, To End a Presidency: The Power of Impeachment (New York: Basic Books, 2018). Tribe, of course, is a Constitutional lawyer and Professor of Constitutional Law (Harvard). His argument is drawn from the text of the American Constitution and the practice of American Constitutional law. Many specialists are persuaded that the American Constitution is defective in a number of ways (bearing on the Executive branch of the government). My own opinion is a philosophical conjecture regarding the inherent informality of constitutional law of any kind applied to a viable state. There are no rules, only the habitude of rules, which ("democrats" hope) would be enough for every unforeseen threat! The rise of totalitarian populism may be modern democracy's undoing.

8 See my Moral Philosophy after 9/11 (University Park: Pennsylvania State University Press, 2004).

9 I take this phrasing from my reading of Peirce. See, further, my Toward a Metaphysics of Culture (London: Routledge, 2016), Ch. 3.

10 See Leo Steinberg, "The Philosophical Brothel," October 44 (1982), pp. 7-74; reprinted, with some additional materials, from its first appearance in Art News (1972).

11 See Ludwig Wittgenstein, Philosophical Investigations, trans. G.E.M. Anscombe (New York: Macmillan, 1953), $\S 219$.

12 See John Dewey, Logic: The Theory of Inquiry [vol. 12, The Later Works, 1925-1953], ed. Jo Ann Boydston (Carbondale: Southern Illinois University Press, 2008 [1986]); and my Toward a Metaphysics of Culture. This last reference may seem an extraneous association. But it is indeed an essential part of my larger venture: to provide (and begin to defend) a reconception of pragmatism, along the lines I favour here. 